\title{
Corporate Social Responsibility as Economic Mechanism for Creating Firm Value
}

\section{Sam Ronald ${ }^{1}$ Suwandi $\mathrm{Ng}^{2}$ | Fransiskus Eduardus Daromes ${ }^{3 *}$ (i)}

${ }^{1}$ Universitas Atma Jaya Makassar, Faculty of Economics and Business, Makassar, Indonesia ${ }^{2}$ Universitas Atma Jaya Makassar, Faculty of Economics and Business, Makassar, Indonesia 3Universitas Atma Jaya Makassar, Faculty of Economics and Business, Makassar, Indonesia

*Correspondence to: Fransiskus Eduardus Daromes, Universitas Atma Jaya Makassar, Faculty of Economics and Business, Jl. Tanjung Alang No. 23, Makassar 90134, Indonesia.

E-mail: daromes@fe.uajm.ac.id

\begin{abstract}
This research is aimed to investigate the influence of corporate social responsibility (CSR) on financial variables such as financial constraints, risks and earnings quality as a mediating aspects for creating firm value. Data were collected from manufacturing companies listed on the Indonesia Stock Exchange for 2013-2016. By using regression and path analysis method, the result shows that CSR has a significant influence on increasing firm value. Meanwhile, the indirect influences show that financial constraints and risk have a positive mediating role in the relationship between CSR and firm value, while the quality of earnings has no mediating role. The finding reveals a difference result with previous studies that CSR has an influence on reducing firm risk. Conflict of stakeholder interest exists as the result of excessive CSR activities and trading noise are used to explain this relationship. This study also indicates that cash flow has better role in increasing firm value compared to the accounting earnings of firm.
\end{abstract}

Keywords: corporate social responsibility, earnings quality, financial constraints, firm value, risk.

Article info: Received 11 October 2018 | revised 30 November 2018 | accepted 23 January 2019

Recommended citation: Ronald, S., Ng, S., \& Daromes, F. E. (2019). Corporate Social Responsibility as Economic Mechanism for Creating Firm Value. Indonesian Journal of Sustainability Accounting and Management, 3(1), 22-36. https://doi.org/10.28992/ijsam.v3i1.69.

\section{INTRODUCTION}

The demand for transparency and reporting accountability is increasing worldwide (KPMG, 2008). Firm has not only contractual responsibilities to conventional stakeholders but also natural responsibility to nature, society and future generations (Zsolnai, 2006). Therefore, firm must perform activities desired by stakeholders, corporate social responsibility (CSR). Reporting CSR in annual report is a mandatory for listed to fulfil Company Act No. 25 year 2007 regarding Capital Investment and Company Act No. 40 year 2007 regarding firm Limited Liability which requires investors and firms to engage social responsibility.

KPMG (2015) argues that the existence of such formal regulations plays an important role in improving corporate responsibility reporting. This is evidenced by the results of KPMG study that Indonesia (with $99 \%$ score) to the second after India (with 100\% score) in the category of developing countries that is very strict to 
reporting responsibility in the world. Firms are encouraged to do this required reporting other wise the firm may face legal consequence. Kim et al. (2012) claim that poor CSR performance would lead to higher legal risks.

CSR is conducted for creating social and environmental benefits. However, the company and the community have long been on debate as the views of economists declared that there is a trade-off between the creation of social benefits and the firm economic success (Porter \& Kramer, 2011).

This may be the trade-off for the company in conducting CSR voluntarily, thus a binding rule is required to encourage it. Therefore, the issue of CSR always discussed, especially in research to investigate the link of CSR and firm financial performance to prove whether CSR can be used as a strategy to meet all stakeholder interests without sacrificing firm economic aspect (van Beurden \& Gössling, 2008; El Ghoul et al., 2011; Crisóstomo et al., 2011; Servaes \& Tamayo, 2013; Gregory et al., 2014; Karim et al., 2016; Bose et al., 2017).

People tend to choose an option that gives them the greatest value for their sacrification (Harrison \& Wicks, 2013). This raises a question whether social activity increases firm value. The logic of the traditional-neo classical view assumes that CSR activities are not in line with the firm's economic goals, therefore it should be avoided (Mackey et al., 2007). This view comes from Friedman (1970) which states that there is one and only one social responsibility of business to use its resources and perform in activities designed to increase profits as long as it stays within the rule of the game. Friedman (1970) assumes that CSR cannot increase the value of the firm. CSR exists because of agency problems that exist within the firm.

Friedman (1970) statement is supported by research of Crisóstomo et al. (2011) who found no relationship between CSR and firm performance and a negative relationship between CSR and firm value. Other studies in line with Friedman's are (Hassel et al., 2005; Brammer et al., 2006). The likelihood of this outcome because there are differences across nations, regions, culture or differences in institutional environments that may affect expectations of stakeholders in regard to CSR activities and reporting (McWilliams et al., 2006). Mackey et al. (2007) also stated that the influence of CSR on firm value is influenced by the level of demand and supply of a social activity. Therefore, in countries with low social demand, CSR will have a negative impact on firm value.

Although Friedman (1970); Hassel et al. (2005); Brammer et al. (2006); Crisóstomo et al. (2011) and there may be other studies that result in negative impact of CSR on firm value, van Beurden \& Gössling (2008) in their paper reviewing the literature for all studies that linked CSR and firm value proxied by firm performance found that the positive relationship (68\%), no relationship (26\%), and negative relationship(6\%). Likewise with Orlitzky et al. (2003) who used a meta-analysis of 52 studies from 1970-1997 discussing CSR and firm performance resulting positive relationship between the two variables. This indicates that CSR is indeed worth considered by managers to be a strategy to increase firm value.

Some previous studies have shown how CSR influenced firm value. Luo \& Bhattacharya (2006); Servaes \& Tamayo (2013) used customer aspect to explain how CSR can increase firm value. Servaes \& Tamayo (2013) stated that the relationship between CSR activity and firm performance through customer aspects is just one way how CSR can affect firm value. Tsoutsoura (2004) stated many variables that can link between CSR and the firm financial performance. Chen et al. (2012) also stated that various channel that can link CSR and firm financial performance are sales, cost, operational efficiency, financing, employee morale and risk. Most of these channel through financial variables. As Pava \& Krausz (1996) categorized financial variables into four major sections: accounting based measurement, market based measurement, risk measurement and other firm characteristics such as financing. This study uses financial variable such as financial constraint, risk and earnings quality to examine the link between CSR and firm value.

This research will use economic aspects instead of customer aspects. Customer aspects are very important for the company because they are directly related to the company's sales level. However, if the 
company also does not pay attention to its operational efficiency, then the approach to the customer is useless because it cannot increase company profits. In addition, company owners do CSR more because they are motivated by economic motives (Graafland \& Mazereeuw-Van der Duijn Schouten, 2012) and key stakeholders usually focus more on this aspect as fundamental (Harrison \& Wicks, 2013). This financial motive is usually something that is preventive in nature for potential costs that might be incurred by the company if it does not do CSR.

Firms with good pollution control are less vulnerable to costly sanctions, and therefore might enjoy lower risk and capital costs (Spicer, 1978). We add earnings quality because employee morale is one of various channels that can link CSR and financial performance (Chen et al., 2012) and earnings quality usually associated with moral level of manager (Kim et al., 2012), the morally person should be less likely to do things like manipulation, so the financial reporting should have good quality. In addition to, we want to test whether earnings or cash flow can predict better the value of the firm.

This research is expected to contribute to reducing the gap between the inconsistency of results in research on CSR and company value. As well as an additional literature review on how CSR can increase company value seen from the financial aspect. This research is also expected to be able to answer traditional economic questions about whether there is a trade-off between social activity and the company's financial performance. Practically, this research is expected to be an encouragement for managers to do CSR more as a strategy that can improve company performance and motivate companies to do voluntary CSR which means not only doing CSR because of the existence of binding regulations. So that the government does not need to carry out tighter supervision of companies related to CSR actions.

Thus, the research question is does CSR has an impact on the creation of firm value through financial variables such as earnings quality, financial constraints and firm risk? To address this question, we use analysis of multiple mediation model developed by Preacher \& Hayes (2008) to test the direct and indirect effect of CSR on firm value. The results show that CSR has direct impact on firm value. Meanwhile, the indirect impact show that financial constraints and risk have mediating role in the relationship between CSR and firm value, but earnings quality doesn't have mediating role. This indicates high CSR firms have higher risk, but the negative effect of risk can be reduced by increasing firm cash flow that can predict the firm value better than accounting earnings. Thus, this study contributes to the literature regarding the impacts of CSR on firm value and to encourage executives to make CSR as a strategy to increase firm value.

\section{METHODS}

The population used in this study was manufacturing firms listed on the Indonesia Stock Exchange (IDX) from 2013-2016 based on the Jakarta Stock Industrial Classification (JASICA). The selection of this periode was due to GRI 4 issued in 2013 and this study uses it in measuring CSR. According to Jakarta Stock Industrial Classification (JASICA) manufacturing industry consist of three main sectors, they are basic and chemical industry, miscellaneous industry, and consumer goods industry. Each sector has several sub-sectors. Basic and chemical industry consist of cement; ceramics, glass, and porcelain; metal and allied products; plastic and packing; animal feed; wood industries; pulp and paper; and others. Miscellaneous industry consists of machinery and heavy equipment; automotive and its components; textiles and garments; footwear; cable; electronic; and others. The consumer goods industry consists of food and beverages; tobacco manufacturers; pharmaceutical; cosmetics and household; housewares; and others. Total sample are 194 unit of analysis based purposive sampling method. 
To test multiple mediation model, we employ script macros which have been developed by Preacher \& Hayes (2008) to facilitate in calculation of direct and indirect influence of CSR to firm value. Preacher \& Hayes (2008) multiple mediation model analysis involve two parts: investigating the total indirect effect, or deciding whether the set of mediators transmits the effect of independent variable to dependent variable and investigating the specific indirect effect associated with each putative mediator. The advantages of using Preacher \& Hayes (2008) multiple mediation model analysis are enabling to test whether there is a simultaneous effect for mediation variable in the relationship of independent and dependent variable, enabling to test specific indirect effect of each mediation variables in the model, reducing bias due to omitted variables, and including several mediators in one model allows the researcher to determine the relative magnitudes of the specific indirect effects associated with all mediators.

To measure CSR, we employ The Global Reporting Initiative (GRI) 4 Guidelines. GRI is suitable to be CSR reporting guideline because indicators are assessed on the economic, social and environmental aspects. GRI has pioneered development and promotion of TBL reporting since 1997 (Ho \& Taylor, 2007) and has been widely used by thousands of large organizations and corporations in America as the basis for the issuance of sustainable financial reporting. This is evidenced by the use of GRI as reference reporting as much as $60 \%$ in 45 countries surveyed (KPMG, 2015). GRI G4 measures CSR by using 91 disclosure items consisting of three main categories: economy, environment, and social. Then, the social category is subdivided into four sub categories: labor practice and decent work, human rights, society, and product responsibility. Each category and sub category have several aspects and each aspect has one or more checklist components. CSR is assessed by conducting content analysis to the firm's reporting and then performing a checklist based on the GRI G4 disclosure items. If an information item is present in the annual report, CSR dummy equals " 1 " and if otherwise it equals "o". Then all the value summed up and divided by the total of CSR disclosure items (91 items) to get CSR value.

Financial constraints occur when firms have limitations to fund profitable investments in order to gain superior performance and competitive advantage (Cheng et al., 2014). Lamont et al. (2001) suggest that the firm limitations in funding this investment are due to credit constraints or the inability to borrow, inability to issue equity, dependence on bank loans, or illiquidity of assets. Kaplan \& Zingales (1997) classify firms based on their level of capital limitations by associating with accounting variables and performing an ordered logit regression. We employ KZ index coefficient in Lamont et al. (2001), the higher the KZ Index the greater the level of the company's capital limitations. According to Lamont et al. (2001) there are five variables in the calculation of KZ index: cash flow to total capital (negative), market to book ratio (positive), debt to total capital (positive), dividend to total capital (negative) and cash holdings to capital (negative). This indicates firms with limited capital tend to have negative cash flow from operations, good corporate values, large debts, small dividend payouts and little cash. When a firm has low cash flow but has a high chance of investing ( $Q$ high), the firm is categorized as financial constraints (Kaplan \& Zingales, 1997). KZ index can be calculated as follow:

$K Z$ Index $=-1.002 \frac{C F_{i t}}{A_{i t-1}}-39.368 \frac{D I V_{i t}}{A_{i t-1}}-1.315 \frac{C_{i t}}{A_{i t-1}}+3.139 L E V_{i t}+0.283 Q_{i t} \ldots$ (1)

Where CFit is the cash flow from operation of firm $\mathrm{i}$ in year $\mathrm{t}$, DIVit is cash dividend of firm $\mathrm{i}$ in year $\mathrm{t}$, Cit is cash balances of firm $i$ in year $t$, LEVit is leverage of firm $i$ in year $t$, Qit is Tobin's $Q$ of firm $i$ in year $t$, and Ait1 is total asset of firm i in previous year. 
Tandelilin (2010) defines risk as a possible difference between the actual return received and the expected return, the bigger the difference the greater the risk of an investment. Risk is divided whether it can be diversified (specific) or not (systematic). Because specific risks can be diversified away then the concern is the systematic risk that is the determinant of the required rate of return and there by the cost of capital (Gregory et al., 2014). CSR can reduces the specific risks experienced by firms by providing good relationships with stakeholders that can create goodwill, thus reducing the cash flow shock when negative events occur (Godfrey et al., 2009). Therefore, this study uses systematic risk in measuring firm risk. We test whether CSR is an activity that can reduces the firm's specific risk can also reduce the systematic risk?

Market risk can be measured by beta, a systematic measure of firm risk (McGuire et al., 1988). Beta can be measured using a market model which is a statistical description of the relationship between the return of an asset and the market return of an asset (Watts \& Zimmerman, 1986). The formula of market model:

$R_{i t}=\alpha_{i}+\beta_{i} R_{m t}+\varepsilon_{i t} \ldots$

Where $\beta i$ is a Raw Beta for stock $i$, Rit is a return of stock $i$ at period $t$, Rmt is a return of market index at period $\mathrm{t}, \mathrm{a}$ is constant, $\varepsilon_{i t}$ is residual reggresion that expected to be white noise (mean of error is zero).

This study uses adjusted beta that has been calculated by PEFINDO which also uses the market model in calculating it, then adjusted to get the value. The use of adjusted beta because in the long term beta value will be close to one. After the value of beta is gotten from the market model, adjusted beta can be calculated as follow:

Adjusted Beta $=\frac{2}{3}\left(\beta_{i}\right)+\frac{1}{3} \ldots$ (3)

Earnings Quality relates to how close the current earnings with future earnings (Rankin et al., 2017). In other words, current earnings which have low correlation with future earnings are said to have low earnings quality. The quality of earnings focus on the accrual role in financial reporting and accruals can be classified as discretionary and non-discretionary accrual. Non-discretionary accruals are a normal part of earnings recognition which is the result of applying neutral accounting rule. Meanwhile, discretionary accruals are the result from the choice of conservative or aggressive accounting policies.

Several studies have used discretionary accrual (DA) to measure the quality of earnings (Prior et al., 2008; Cornett et al., 2008; Kim et al., 2012); and it is most powerful in detecting earnings management (Cornett et al., 2008) therefore this study uses DA to assess the earnings quality of firm. DA is calculated using the Modified Jones Model developed by Dechow et al. (1995). According to him, this modification model was made to eliminate possible error tendencies in measuring discretionary accrual by Jones's model when discretion exercised over revenues. Modified Jones Model assumes that all changes to credit sales in a given period are the result of earnings management because it is easier to exercise earnings management on revenue due to credit sales than for cash sales. DA value can be positive (income maximization) or negative (income minimization), but this research does not want to see its direction but from the amount of DA value which is the result of the management intention to manage its earnings. According to Cornett et al. (2008) the use of absolute value is the most appropriate measure in measuring earnings management.

$D A_{i t}=\frac{T A_{i t}}{A_{i t-1}}-N D A_{i t} \ldots$ (4) 
Where DAit is discretionary accruals from firm $i$ in year $t$, TAit is total accrual from firm $i$ in year $t$ by deducted net income and cash flow from operation, Ait- 1 is total asset from firm i in year $t$, NDAit is nondiscretionary accruals from firm i in year $t$ calculated using NDA by modified Jones Model (Dechow et al., 1995).

Harrison \& Wicks (2013) defines value as anything that has potential benefits for stakeholders. Firm creates the value of its activities and the stakeholders want to achieve utility from its relationship with the firm by obtaining that value. The value of this firm can be seen from the value of Tobin's Q (Value Q), interpreted as market expectations of the economic returns generated from the firm's assets (Gaio \& Raposo, 2011), and this is commonly used in conducting market value analysis. The advantage of using Tobin's Q over profitability is that Tobin's $Q$ is long term because based on the market value of the firm (Servaes \& Tamayo, 2013). The measurement using market value has an advantage over using the measurement of accounting values, that is less affected by differences in accounting procedures and managerial manipulation and represents investor's evaluation of the firm's ability to generate future economic earnings rather than past performance (McGuire et al., 1988). Tobin's $Q$ has been used extensively in economics, finance and strategy when measuring firm performance (Luo \& Bhattacharya, 2006; Gaio \& Raposo, 2011; Crisóstomo et al., 2011; Servaes \& Tamayo, 2013). Following formula is used to calculate the Tobin's Q:

$Q_{i t}=\frac{B V A_{i t}+M V E_{i t}-B V E_{i t}}{B V A_{i t}} \ldots$ (5)

Where Qit is value of Tobin's $Q$ from firm $i$ in year $t$, BVAit is book value of total asset of firm $i$ in year $t$, MVEit is market value of equity of firm $i$ in year $t$, BVEit is book value of equity of firm i in year $t$.

\section{RESULTS AND DISCUSSION}

Table 1 shows the minimum CSRD value is 0.15 , the maximum value is 0.52 and the mean value is 0.27 . This indicates that the average manufacturing firm lacks of CSR disclosure in accordance with the guidelines of GRI G4. The minimum value of FC is -1.64 , the maximum value is 3.66 and the mean value is 0.36 . The higher FC value indicates the greater the firm's capital limitations. The mean value is 0.36 indicates that the average firm in this study has limited capital. The minimum value of FR is 0.34 , the maximum value is 2.23 and the mean value is 0.89. This indicates that the average sample firm has low risk because the value of FR measured by beta has a value $<1$, means its stock return volatility is smaller than the market index. The minimum value of EQ is -6.33 , the maximum value is -0.64 and the mean value is 3.29 . This shows that the average firm tends to conduct earnings management so earnings becomes less qualified. The minimum value of $F Q$ is -1.09 , the maximum value is 1.04 and a mean value is 0.18 . A positive $F Q$ score indicates that an additional value obtained by the firm because of the market value of the stock is higher than the book value of stock. A mean value of 0.18 indicates that the average firm has an increase in its value, but it is not too significant. The minimum value of SIZE is 134 , the maximum value is 261,855 and the mean value is 11,074 . This shows that the average firm is small.

Table 2 shows the results of direct effects of independent variable (CSRD) on the mediator variables in this study (FC, FR, and EQ) are called a paths. It results that CSRD has negative impact on $F C(-1.6451, p<0.05)$, while CSRD has positive impact on FR $(1.7908, p<0.05)$, but CSRD has no impact on EQ $(-1.4264, p>0.05)$. For $b$ paths that show direct effects of mediators on dependent variable (FQ) result $F C$ has negative impact on $F Q$ $(-0.1395, \mathrm{p}<0.05)$, FR has positive impact on FQ $(0.2199, \mathrm{p}<0.05)$ and EQ has no impact on FQ $(0.0247, \mathrm{p}>$ $0.05)$. For the direct effects of independent variable (CSRD) on dependent variable (FQ) after controlling all mediator variables called c' path resulting that CSRD has positive impact on increasing FQ $(1.8057, p<0.05)$, so 
$\mathrm{H} 1$ accepted. The total effects independent variable on dependent variable called $\mathrm{c}$ path result significant impact $(p<0.05)$, thus the model used in this study is feasible.

Table 1 Descriptive Statistic

\begin{tabular}{cccccc}
\hline Variable & $\mathrm{N}$ & Minimum & Maximum & Mean & Std. Deviation \\
\hline CSRD & 194 & 0.15 & 0.52 & 0.27 & 0.07 \\
FC & 194 & $(1.64)$ & 3.66 & 0.36 & 0.78 \\
FR & 194 & 0.34 & 2.23 & $(3.29)$ & 0.36 \\
EQ & 194 & $(6.33)$ & $(0.64)$ & 0.18 & 1.10 \\
FQ & 194 & $(1.09)$ & 1.04 & 11,074 & 0.38 \\
SIZE & 194 & 134 & 261,855 & 36,175 \\
\hline
\end{tabular}

$\mathrm{CSRD}=$ square root (SQRT) from total score of Corporate Social Responsibility Disclosure, FC = Financial Constraint, $\mathrm{FR}=$ Firm Risk, EQ = Earnings Quality is measure by natural log of absolute DA, FQ = natural log of firm value measured by Tobin's Q, SIZE = size of firm measured by total asset in billion rupiahs

Table 2 Regression Results

\begin{tabular}{|c|c|c|c|c|}
\hline Description & Coefficient & SE & $\mathrm{t}$ & p-value \\
\hline \multicolumn{5}{|c|}{ Direct Effects of Independent Variable on Mediators (a paths) } \\
\hline $\mathrm{FC}(\mathrm{a} 1)$ & -1.6451 & 0.7998 & -2.0568 & 0.0411 \\
\hline $\mathrm{FR}(\mathrm{a} 2)$ & 1.7908 & 0.3528 & 5.0759 & 0.0000 \\
\hline $\mathrm{EQ}(\mathrm{a} 3)$ & -1.4264 & 1.1385 & -1.2529 & 0.2118 \\
\hline \multicolumn{5}{|c|}{ Direct Effects of Mediators on Dependent Variable (b paths) } \\
\hline $\mathrm{FC}(\mathrm{b} 1)$ & -0.1395 & 0.0300 & -4.6494 & 0.0000 \\
\hline $\mathrm{FR}(\mathrm{b} 2)$ & 0.2199 & 0.0684 & 3.2156 & 0.0015 \\
\hline EQ (b3) & 0.0247 & 0.0212 & 1.165 & 0.2455 \\
\hline \multicolumn{5}{|c|}{ Direct Effects of Independent Variable on Dependent Variable (c' path) } \\
\hline CSRD (c' path) & 1.8057 & 0.3585 & 5.0365 & 0.0000 \\
\hline \multicolumn{5}{|c|}{ Total Effects of Independent Variable on Dependent Variable (c path) } \\
\hline CSRD (c path) & 2.3939 & 0.3561 & 6.7225 & 0.0000 \\
\hline
\end{tabular}

Table 3 Multiple Mediation Analysis

\begin{tabular}{|c|c|c|c|c|c|c|c|}
\hline \multirow[t]{3}{*}{ Description } & \multirow{3}{*}{$\begin{array}{c}\text { Point } \\
\text { Estimate }\end{array}$} & \multirow[t]{3}{*}{ SE } & \multirow{3}{*}{$\begin{array}{c}\mathrm{p}- \\
\text { value }\end{array}$} & \multicolumn{4}{|c|}{ Bootstrapping 1000 Sample, Cl 95\% } \\
\hline & & & & \multicolumn{2}{|c|}{ Bias Corrected (BC) } & \multicolumn{2}{|c|}{$\begin{array}{c}\text { Bias Corrected } \\
\text { Accelerated (BCa) }\end{array}$} \\
\hline & & & & LL & UL & LL & UL \\
\hline FC-Financial Constraint (a1b1) & 0.23 & 0.13 & 0.06 & 0.02 & 0.55 & 0.02 & 0.55 \\
\hline FR-Firm Risk (a2b2) & 0.39 & 0.16 & 0.01 & 0.13 & 0.76 & 0.12 & 0.75 \\
\hline EQ-Earnings Quality (azb3) & $(0.04)$ & 0.04 & 0.39 & $(0.19)$ & 0.02 & $(0.19)$ & 0.02 \\
\hline Total Indirect Effect & 0.59 & 0.22 & 0.00 & 0.21 & 1.04 & 0.22 & 1.06 \\
\hline Direct Effect $\left(c^{\prime}\right)$ & 1.81 & 0.36 & 0.00 & & & & \\
\hline Total Effect (c) & 2.39 & 0.36 & 0.00 & & & & \\
\hline
\end{tabular}

We use Preacher \& Hayes (2008) bootstrap method to investigate the specific indirect effects of multiple mediation model. If the confidence interval value of lower limit (LL) and upper limit (UL) do not contain zero, the mediating variable has significant effect. Table 3 shown the results of three mediator used in this study. The specific indirect effect of $\mathrm{FC}(\mathrm{BCa} 95 \% \mathrm{Cl}$ of 0.02 to 0.55$)$ is significant because the confidence interval do not contain zero. This indicate that CSR has significant impact on reducing financial constraint, thereby increasing firm value, so the $\mathrm{H} 2$ is accepted. The specific indirect effect of $\mathrm{FR}(\mathrm{BCa} 95 \% \mathrm{Cl}$ of 0.12 to 0.75 ) also 
show significant effect, but $\mathrm{H} 3$ is rejected because CSR has positive impact on increasing firm risk, not negative impact. While, EQ ( $\mathrm{BCa} 95 \% \mathrm{Cl}-0.19$ to 0.02 ) has no effect. It means the quality of earnings is not determined by CSR and is not a factor that determines the firm value, thus $\mathrm{H}_{4}$ is rejected. Because CSR has direct impact on firm value, financial constraints and firm risk have partial mediating role in increasing firm value.

The results of this study are consistent with the value creation school such as Siregar \& Bachtiar (2010), Servaes \& Tamayo (2013), Karim et al. (2016); Onuorah et al. (2018) that doing CSR can increase firm value directly. This is because CSR can enhance the firm's reputation such as positive image, smooth supply chain, high customer and employee loyalty, and maintain high level of public and investor trust. This intangible thing is valuable because it is difficult to be imitated by other firms, so it is an advantage for high CSR firms compared to low CSR firms. In addition, this study also investigates how CSR can increase this value. We find that the reducing of firm financial constraint and increasing of firm systematic risks due to the implementation of CSR are the causes of increasing of firm value.

Firms are considered more financially constrained when the wedge between internal and external cost of capitals increases (Kaplan \& Zingales, 1997). One of the causes of firms experiencing financial constraints is information asymmetry (Fazzari et al., 1988). This asymmetry is lack of investor knowledge about firm's performance, problems or risks that could lead to agency costs such as monitoring costs. Investors will usually ask for compensation in the form of higher interest rates because of this information risks, causing the external cost of capital also to be high. CSR can reduce this information asymmetries because it provides information on the economic, social and environmental aspects of firm. When investors have sufficient information, they will be easier to asses firms without having to pay for third party services or gather more information so the agency costs will decrease.

CSR is form of stakeholder approach, means striving to be able to meet all stakeholder interests that aims to be able to prevent unfavorable events and facilitate the firm's operations. Firm that meet the interests of these stakeholders will provide utilities thus it can maintain their participation and support (Harrison \& Wicks, 2013) that will provide long-term benefits to the firm. For example, high reputation and trust by consumers can increase sales, high employee loyalty and environmental impact prevention efforts can improve cost efficiency, and high investor confidence can increase firm capital. When cash is available, all operations will run well because everything can be funded and firm does not need to finance using debts that have high interest costs or the issuance of new shares that have large transaction costs, thereby reducing firm financial constraints.

Thus, firms can reduce the specific risks of unfortunate events by having good cash flow. Not only that, the benefits gained by having good funding can make firm has competitive advantage because it can make profitable investments such as research and development that can create product innovation, improve the quality of product, reduce the risk of litigation due to environmental problems or due to the inability to repay the debt, maintain the relationship with society, increase the welfare of employee to decrease turn over, so as to enhance the reputation and value of the firm. Our results is consistent with (Cheng et al., 2014) that CSR has significant impact on decreasing firm financial constraints and with (Lamont et al., 2001) that financial constraint has negative impact on increasing firm value.

Our study also shows increasing risk experienced by firm has mediation role in the relationship between CSR and firm value. The result of this study is inconsistent with previous studies that resulted in CSR having an influence in reducing firm risk (Salama et al., 2011; Gregory et al., 2014). Nguyen \& Nguyen (2015) study showed CSR can increase firm risk, but the result is not linear because they found that both CSR strength and CSR concerns measured by KLD Research \& Analytics, Inc. can increase risk. To explain this result, we use stakeholder conflict and noise trading. 
First, stakeholder conflict can occur because of fulfillment of the instrumental and normative aspects of a firm that must be satisfied equally and jointly. As Freeman (1984) defines stakeholders as any groups or individuals who can affect or is affected by the achievement of firm to achieve its goals. Individuals who can affect is an instrumental aspect of stakeholder theory in order for firm to get maximum profit, while those who can affected is the normative aspect of this theory because the firm has a moral obligation to its stakeholders (Berman et al., 1999). If firm focuses too much on one aspect it can create conflict between stakeholders and this is most likely to happen to a large firms as more stakeholders are involved in the firm. Data in this study show that the average firm with high CSR has large size measured by total asset. McGuire et al. (1988); Salama et al. (2011); Gregory et al. (2014) also yields the same result that the size of the firm as measured by its assets has a positive correlation with CSR. Parties that affect the activities of firms (instrumental aspect) such as owners and shareholders tend to be more focus on economic performance such as profit, while those affected by firm activity (normative aspect) will tend to focus on firms moral obligations to the surrounding environment. Thus, CSR can be said to be a conflict of claims from various stakeholder groups, more attention to the interests of one stakeholder group is a cost to other stakeholder groups (Nguyen \& Nguyen, 2015).

Excessive CSR activity for normative aspect can reduce the competitive advantage because the firm's funds are allocated at something that does not produce economic benefits in the future. Nguyen \& Nguyen (2015) study proved that individual component of CSR which are divided into strength and concern if associated with risk, show inconsistent results. Components such as employee, diversity and governance, have a significant positive impact on firm risk both in terms of strength and its concern. This means the lack of attention to these three components may increase firm risk, but if the company increases CSR too much in this area it can also increase firm risk. They argue that CSR activities such as excessive health care benefits for employees, recruiting managers with diverse backgrounds but may not have the appropriate capabilities, and over-disclosure of firm information that could makes stock prices fall are CSR activities that have expense greater than the benefits.

Table 4 Individual Components of CSR on Firm Risk

\begin{tabular}{|c|c|c|c|c|c|}
\hline CSR Components & B & Sig. & CSR Components & B & Sig. \\
\hline \multicolumn{3}{|c|}{ Panel A Before Controlling Size } & \multicolumn{3}{|c|}{ Panel B After Controlling Size } \\
\hline EC & 0.39 & 0.28 & EC & 0.68 & 0.14 \\
\hline EN & $(1.45)$ & 0.08 & EN & $(1.82)$ & 0.05 \\
\hline LA & 2.09 & 0.00 & LA & 2.20 & 0.00 \\
\hline HR & $(0.95)$ & 0.13 & $\mathrm{HR}$ & $(1.05)$ & 0.10 \\
\hline SO & 0.25 & 0.58 & SO & 0.21 & 0.64 \\
\hline PR & 0.27 & 0.40 & PR & 0.29 & 0.36 \\
\hline & & & SIZE & $(0.00)$ & 0.31 \\
\hline
\end{tabular}

EC = Economic; EN = Environment; LA = Labor; HR = Human Rights; SO = Social; PR = Products

We also test for our individual component of CSR to be able to explain better what component of CSR could increase firm risk. The results showed in Table 4, for economic, labor, social, and product components have a positive impact on risk, but only labor has significant impact before and after controlling size. This is consistent with the results of the Nguyen \& Nguyen (2015) study that excessive costs for employees benefit can increase the firm risk due to the allocation of funds too large to the workforce, while for development in order to increase the competitive advantage is reduced, thus the risk of the firm will increase because of market competition risk. For environmental and human rights components have a negative impact on risk, but only the environment has a significant impact in reducing firm risk (after controlling the size). This shows that 
environmental problems are very influential in reducing risk for large firms. Environmental costs are large but if the company has good environmental control it can prevent greater costs such as legal sanctions or compensations imposed to firm as a responsibility for damaging the environment, thereby reducing possible environment and legal risks experienced by firm. While the aggregate CSR scoring has a significant positive impact in increasing firm risk (see Table 2 ) because labor coefficient $(B=2.2)$ that has greater value than environmental coefficient $(B=-1.82)$. This indicates that good control of the environment has a preventive benefit, but it can't generate direct resources for the firm while the increasing welfare of employees directly uses the firm's resources in the form of large cash, thus firm cannot allocate funds to activities that can increase competitive advantage.

Another argument for positive impact of CSR on firm risk can be explained using the concept of noise trading by Orlitzky (2013) in his paper entitled Corporate Social Responsibility, Noise, and Stock Market Volatility. This research explained that noise trading makes the market rates CSR highly, causing the volatility of firm's stock price will increase dramatically. Noise trading is a stock trading transaction whose decisionmaking is based on rational rather than fundamental analysis.

Orlitzky (2013) explains there are two main reasons that cause noise trading. First, the ambivalent economic impact of CSR. Various studies have been done how CSR produces diverse results if associated with firm performance, there are positive and negative but most positive results are obtained (Orlitzky et al., 2003; van Beurden \& Gössling, 2008). This will cause investors to rely on CSR information in making decisions because of the positive impact it has. Second, the presence of information asymmetry arises because of the seller (the firm) has more information than the buyer (investor) about the activity and impact of CSR activities. This can be exploited by opportunistic managers to manage their reporting by exaggerating the scope and extent of CSR disclosure. Managers can also influence investors, especially altruistic investors are more easily affected because CSR is a good thing and can increase firm value. Both of these, will make investors take a decision based on rationalization rather than fundamentals, thus increasing demand for shares of firms with high CSR. This increased demand will also increase stock prices (Mackey et al., 2007), so the stock volatility exceed the market index (Orlitzky, 2013). When a firm's stock has a volatility that exceeds the market index, it means firm has high risk. Risk is measured by beta in this study, defined as volatility of a security or portfolio, the greater the volatility, the higher the risks. Based on these arguments, CSR indeed could have significant positive impact in increasing the firm risk.

Investors only want to make risky investments, if only they expecting more reward (a positive relationship between risk and return). This study has proved the modern portfolio theory developed by Markowitz (1952) that risk has a significant positive impact on increasing firm value. Thus, this study supports Shin \& Stulz (2000) study which results systematic risk has significant positive impact on $Q$ value because this types of firms have high growth rate that can drive higher $Q$ value.

Therefore, firms with high CSR will be highly valued by the market because of the many positive impacts that CSR has, such as reducing financial constraints (Cheng et al., 2014), becoming recommendations in investment decision making (Spicer, 1978; Ioannou \& Serafeim, 2015), improving performance (Pava \& Krausz, 1996), reducing litigation risks (Chen et al., 2012) and many more that can shape investor confidence in CSR's ability to increase firm value. This formed trust making some investors judge high CSR firms are as performed well firms, making their decision without considering fundamental analysis, especially for high social awareness investors (Orlitzky, 2013), thereby increasing firm stock demand which then adjusts to the firm's stock price. When a stock price rises far above market value, it will increase volatility which means having high risk and so will Q value, because the market value is higher than the book value of firm stock. 
Our study also found, there is no mediation role of earnings quality in the relationship between CSR and firm value. This result indicates that CSR has no relationship to the management discretion of its earnings and is not a driver of firm value. So, it can be said that earnings is not a driver that can increase stakeholder support, thus increasing firm value. The stakeholder preference when providing support to firm depends on how their transactions, relationships and interactions with the firm affect the utility they get (Harrison \& Wicks, 2013). The greater the utility the firm can give the larger the stakeholder satisfaction, so higher valuation of the firm. For example, when an investor makes an investment decision will expect on the dividend payout and how much the rate of return can be earned from the stock price of the firm that exceeds the book value and market index. The investors or shareholders are the stakeholder of firm who seek to maximize their claims and if firm can comply, it will simultaneously maximize other stakeholder claims (Copeland et al., 1994).

In addition, high earnings quality does not indicate that firm can allocate its funding to increase the utility of other primary stakeholders. Because earnings are part of accruals while to improve stakeholder utilities such as improving employee welfare, improving product quality, providing social assistance, maintaining the environment is an activity that requires cash. So the quality of earnings cannot be used as a benchmark for stakeholders that the firm will provide utilities and can balance all the interests of its stakeholders. This study is consistent with $\mathrm{Ng} \&$ Daromes (2016) which shows that financial performance has no effect on firm value. This is probably because not all companies will distribute their earnings to shareholders. To grow and expand, companies will need more funding for future sources of financing in addition to sources of funds from debt and corporate equity. If the company's profitability increases, it is likely that managers will use net income to expand their business and expand rather than share profits with shareholders. Therefore investors cannot make financial indicators as a single indicator in making investment decisions, but also must consider social factors, environment, politics and management policies.

\section{CONCLUSION}

Based on the results of this study it can be concluded that financial variables such as financial constraint and risk have a partial role in mediating the relationship between CSR and firm value because CSR can directly increase the value. CSR reduces financial constraints experienced by firms due to increased sales, cost efficiency, and reduced cost of capital, thus allowing firms to make favourable investments that can ultimately increase the value of the firms. However, the risk is not reduced by the presence of CSR, but rather increases. This is because there is a conflict of interest between stakeholders. In addition, the overestimate stakeholder expectations of CSR make their decision making more likely to use rationalization rather than fundamental analysis resulting in high volatility of stocks and firm values. Meanwhile, earnings quality has no mediation role in relationship between CSR and firm value. This indicates that firms conduct CSR not because they are ethic or more transparent, but because they want to comply with applicable regulations, to meet people's expectations and to gain competitive advantage. Earnings quality also has no impact in increasing firm value because it is part of accruals that cannot guarantee increasing utilities for its stakeholders. Utilities can only be obtained from allocated cash by firm that can be used to get stakeholder support.

The implication of this study is to be an additional literature and new perspective especially how CSR can increase firm value. This study supports value creation school groups that high CSR has positive impact in increasing firm value and suggests managers to focus more on the firm's cash flow than just generate large earnings. Firm can increase cash flow by doing CSR because it can reduce the financial constraints, thus indirectly reduce specific risks. When a firm has large capital, it can be used to meet various stakeholder 
interests, increase competitive advantage, enhance firm's reputation and ultimately increase the firm value. Therefore, this study encourages firms to conduct and disclose more CSR to increase transparency and compliance with government regulations. In addition, this study also encourages the implementation of philanthropic CSR because the good thing (the implementation of CSR) will produce the good results (increasing value) for firm.

This study has limitations, especially in number of samples that are still limited to manufacturing firms in Indonesia. Different results may occur by using more samples, for example by including all firms in Indonesia or even globally. The impact of CSR reporting may vary by country, region, culture or institutional environment that affects stakeholder expectations of CSR activity and reporting (McWilliams et al., 2006). Another limitation is this study only measures risk using beta as systematic risk, while Shin \& Stulz (2000) use systematic, specific and total risks to get more specific explanations. Gregory et al. (2014) measures systematic risk not only by beta but, also growth rate, market factor, size factor and value/growth factor. Meanwhile, McGuire et al. (1988) measure the specific risk by risk-adjusted return, and accounting risk using debt to assets, operating leverage, and the standard deviation of operating income. Future research is expected to use different risk measurements to explain better and specifically how the impact of CSR on firm risk.

Future studies can be investigated as development of our study are to investigate what the motives of managers in doing CSR and what if this motive is associated with CSR disclosure and earnings quality. This is conducted to see how the difference between extrinsic and intrinsic manager in their decision making that has economic impact. Measurement of managerial orientation towards CSR can be seen in study of Graafland \& Mazereeuw-Van der Duijn Schouten (2012). Extrinsic managers who prefer economic performance should be less in conducting CSR and tend to dso discretion so lower the earnings quality, while the intrinsic manager otherwise because it has a good ethical understanding. Another research question is what information investor used in making their investment decision, whether the earnings, cash flow or any other information, then these will be associated with the activity of stock transactions and its value to find out what making firm value high. This is conducted to see if noise trading generally done by investor in Indonesia, if not what information they used. The concept of noise trading and its relation to stock volatility can be seen in (Orlitzky, 2013).

\section{ORCID}

Fransiskus Eduardus Daromes (1) https://orcid.org/0000-0002-7268-673X

\section{REFERENCES}

Berman, S. L., Wicks, A. C., Kotha, S., \& Jones, T. M. (1999). Does Stakeholder Orientation Matter? The Relationship Between Stakeholder Management Models and Firm Financial Performance. Academy of Management Journal, 42(5), 488-506. https://doi.org/10.5465/256972

Bose, S., Podder, J., \& Biswas, K. (2017). Philanthropic Giving, Market-Based Performance and Institutional Ownership: Evidence from an Emerging Economy. The British Accounting Review, 49(4), 429-444. https://doi.org/10.1016/j.bar.2016.11.001

Brammer, S., Brooks, C., \& Pavelin, S. (2006). Corporate Social Performance and Stock Returns: UK Evidence from Disaggregate Measures. Financial Management, 35(3), 97-116. https://doi.org/10.1111/j.1755053X.2006.tbo0149.x

Chen, L., Srinidhi, B., Tsang, A., \& Yu, W. (2012). Corporate Social Responsibility, Audit Fees, and Audit Opinions. In AAA Auditing Section Midyear Conference. 
Cheng, B., loannou, I., \& Serafeim, G. (2014). Corporate Social Responsibility and Access to Finance. Strategic Management Journal, 35(1), 1-23. https://doi.org/10.1002/smj.2131

Copeland, T., Koller, T., \& Murrin, J. (1994). Valuation: Measuring and Managing the Value of Companies. New York: John Wiley \& Sons.

Cornett, M. M., Marcus, A. J., \& Tehranian, H. (2008). Corporate Governance and Pay-For-Performance: The Impact of Earnings Management. Journal of Financial Economics, 87(2), 357-373. https://doi.org/10.1016/j.jfineco.2007.03.003

Crisóstomo, V. L., Freire, F. de S., \& Vasconcellos, F. C. de. (2011). Corporate Social Responsibility, Firm Value and Financial Performance in Brazil. Social Responsibility Journal, 7(2), 295-309. https://doi.org/10.1108/17471111111141549

Dechow, P. M., Sloan, R. G., \& Sweeney, A. P. (1995). Detecting Earnings Management. The Accounting Review, 70(2), 193-225.

El Ghoul, S., Guedhami, O., Kwok, C. C. Y., \& Mishra, D. R. (2011). Does Corporate Social Responsibility Affect the Cost of Capital? Journal of Banking and Finance, 35(9), 2388-2406. https://doi.org/10.1016/j.jbankfin.2011.02.007

Fazzari, S. M., Hubbard, R. G., Petersen, B. C., Blinder, A. S., \& Poterba, J. M. (1988). Financing Constraints and Corporate Investment. Brookings Papers on Economic Activity, 1988(1), 141-206.

Freeman, R. E. (1984). Strategic Management: A Stakeholder Approach. Boston: Pitman.

Friedman, M. (1970). The Social Responsibility of Business is to Increase its Profits. The New York Times Magazine.

Gaio, C., \& Raposo, C. (2011). Earnings Quality and Firm Valuation: International Evidence. Accounting and Finance, 51(2), 467-499. https://doi.org/10.1111/j.1467-629X.2010.00362.X

Godfrey, P. C., Merrill, C. B., \& Hansen, J. M. (2009). The Relationship between Corporate Social Responsibility and Shareholder Value: An Empirical Test of the Risk Management Hypothesis. Strategic Management Journal, 30(4), 425-445. https://doi.org/10.1002/smj.750

Graafland, J., \& Mazereeuw-Van der Duijn Schouten, C. (2012). Motives for Corporate Social Responsibility. De Economist, 160(4), 377-396. https://doi.org/10.1007/s10645-012-9198-5

Gregory, A., Tharyan, R., \& Whittaker, J. (2014). Corporate Social Responsibility and Firm Value: Disaggregating the Effects on Cash Flow, Risk and Growth. Journal of Business Ethics, 124(4), 633-657. https://doi.org/10.1007/s10551-013-1898-5

Harrison, J. S., \& Wicks, A. C. (2013). Stakeholder Theory, Value, and Firm Performance. Business Ethics Quarterly, 23(1), 97-124. https://doi.org/10.5840/beq20132314

Hassel, L., Nilsson, H., \& Nyquist, S. (2005). The Value Relevance of Environmental Performance. European Accounting Review, 14(1), 41-61. https://doi.org/10.1080/0963818042000279722

Ho, L. J., \& Taylor, M. E. (2007). An Empirical Analysis of Triple Bottom-Line Reporting and its Determinants: Evidence from the United States and Japan. Journal of International Financial Management and Accounting, 18(2), 123-150. https://doi.org/10.1111/j.1467-646X.2007.01010.x

Ioannou, I., \& Serafeim, G. (2015). The Impact of Corporate Social Responsibility on Investment Recommendations: Analysts' Perceptions and Shifting Institutional Logics. Strategic Management Journal, 36(7), 1053-1081. https://doi.org/10.1002/smj.2268

Kaplan, S. N., \& Zingales, L. (1997). Do Investment-Cash Flow Sensitivities Provide Useful Measures of Financing Constraints? The Quarterly Journal of Economics, 112(1), 169-215. https://doi.org/10.1162/003355397555163

Karim, K., Suh, S., \& Tang, J. (2016). Do Ethical Firms Create Value? Social Responsibility Journal, 12(1), 54-68. https://doi.org/10.1108/SRJ-09-2014-0127

Kim, Y., Park, M. S., \& Wier, B. (2012). Is Earnings Quality Associated with Corporate Social Responsibility? The Accounting Review, 87(3), 761-796. https://doi.org/10.2308/accr-10209

KPMG. (2008). KPMG International Survey of Corporate Responsibility Reporting 2008. Amstelveen: KPMG International.

KPMG. (2015). The KPMG Survey of Corporate Responsibility Reporting 2015. 
Lamont, O., Polk, C., \& Saaá-Requejo, J. (2001). Financial Constraints and Stock Returns. Review of Financial Studies, 14(2), 529-554. https://doi.org/10.1093/rfs/14.2.529

Luo, X., \& Bhattacharya, C. B. (2006). Corporate Social Responsibility, Customer Satisfaction, and Market Value. Journal of Marketing, 70(4), 1-18. https://doi.org/10.1509/jmkg.70.4.001

Mackey, A., Mackey, T. B., \& Barney, J. B. (2007). Corporate Social Responsibility and Firm Performance: Investor Preferences and Corporate Strategies. Academy of Management Review, 32(3), 817-835.

Markowitz, H. (1952). Portfolio Selection. The Journal of Finance, 7(1), 77-91. https://doi.org/10.1111/j.15406261.1952.tb01525.x

McGuire, J. B., Sundgren, A., \& Schneeweis, T. (1988). Corporate Social Responsibility and Firm Financial Performance. Academy of Management Journal, 31(4), 854-872. https://doi.org/10.5465/256342

McWilliams, A., Siegel, D. S., \& Wright, P. M. (2006). Corporate Social Responsibility: International Perspectives (Rensselaer Working Papers in Economics No. 0604).

Ng, S., \& Daromes, F. E. (2016). Peran Kemampuan Manajerial sebagai Mekanisme Peningkatan Kualitas Laba dan Nilai Perusahaan. Jurnal Akuntansi Dan Keuangan Indonesia, 13(2), 174-193. https://doi.org/10.21002/jaki.2016.10

Nguyen, P., \& Nguyen, A. (2015). The Effect of Corporate Social Responsibility on Firm Risk. Social Responsibility Journal, 11(2), 324-339. https://doi.org/10.1108/SRJ-08-2013-0093

Onuorah, O. A., Egbunike, F. C., \& Gunardi, A. (2018). The Influence of Corporate Board Attributes on Voluntary Social Disclosure of Selected Quoted Manufacturing Firms in Nigeria. Indonesian Journal of Applied Business and Economic Research, 1(1), 20-33.

Orlitzky, M. (2013). Corporate Social Responsibility, Noise, and Stock Market Volatility. Academy of Management Perspectives, 27(3), 238-254. https://doi.org/10.5465/amp.2012.0097

Orlitzky, M., Schmidt, F. L., \& Rynes, S. L. (2003). Corporate Social and Financial Performance: A Meta-Analysis. Organization Studies, 24(3), 403-441. https://doi.org/10.1177/0170840603024003910

Pava, M. L., \& Krausz, J. (1996). The Association between Corporate Social-Responsibility and Financial Performance: The Paradox of Social Cost. Journal of Business Ethics, 15(3), 321-357. https://doi.org/10.1007/BFo0382958

Porter, M. E., \& Kramer, M. R. (2011). The Big Idea: Creating Shared Value. Harvard Business Review.

Preacher, K. J., \& Hayes, A. F. (2008). Asymptotic and Resampling Strategies for Assessing and Comparing Indirect Effects in Multiple Mediator Models. Behavior Research Methods, 40(3), 879-891. https://doi.org/10.3758/BRM.40.3.879

Prior, D., Surroca, J., \& Tribó, J. A. (2008). Are Socially Responsible Managers Really Ethical? Exploring the Relationship Between Earnings Management and Corporate Social Responsibility. Corporate Governance: An International Review, 16(3), 160-177. https://doi.org/10.1111/j.1467-8683.2008.00678.x

Rankin, M., Ferlauto, K., McGowan, S., \& McGowan, P. (2017). Contemporary Issues in Accounting (2nd ed.). Wiley.

Salama, A., Anderson, K., \& Toms, J. S. (2011). Does Community and Environmental Responsibility Affect Firm Risk? Evidence from UK Panel Data 1994-2006. Business Ethics: A European Review, 20(2), 192-204. https://doi.org/10.1111/j.1467-8608.2011.01617.x

Servaes, H., \& Tamayo, A. (2013). The Impact of Corporate Social Responsibility on Firm Value: The Role of Customer Awareness. Management Science, 59(5), 1045-1061. https://doi.org/10.1287/mnsc.1120.1630

Shin, H.-H., \& Stulz, R. M. (2000). Firm Value, Risk, and Growth Opportunities (NBER Working Paper No. 7808).

Siregar, S. V., \& Bachtiar, Y. (2010). Corporate Social Reporting: Empirical Evidence from Indonesia Stock Exchange. International Journal of Islamic and Middle Eastern Finance and Management, 3(3), 241-252. https://doi.org/10.1108/17538391011072435

Spicer, B. H. (1978). Investors, Corporate Social Performance and Information Disclosure: An Empirical Study. Accounting Review, 53(1), 94-111.

Tandelilin, E. (2010). Portofolio dan Investasi: Teori dan Aplikasi (1st ed.). Yogyakarta: Kanisius.

Tsoutsoura, M. (2004). Corporate Social Responsibility and Financial Performance. UC Berkeley: Center for Responsible Business. 
van Beurden, P., \& Gössling, T. (2008). The Worth of Values - A Literature Review on the Relation Between Corporate Social and Financial Performance. Journal of Business Ethics, 82(2), 407-424. https://doi.org/10.1007/s10551-008-9894-x

Watts, R. L., \& Zimmerman, J. L. (1986). Positive Accounting Theory. Englewood Cliffs: Prentice-Hall.

Zsolnai, L. (2006). Extended Stakeholder Theory. Society and Business Review, 1(1), 37-44. https://doi.org/10.1108/17465680610643337 